\title{
HABITAT USE BY Oryzomys subflavus (RODENTIA) IN AN OPEN SHRUBLAND FORMATION IN RESTINGA DE JURUBATIBA NATIONAL PARK, RJ, BRAZIL
}

\author{
BERGALLO, H. G. ${ }^{1}$, LUZ, J. L. ${ }^{2}$, RAÍCES, D. S. ${ }^{2}$, \\ HATANO, F. H. ${ }^{2}$ and MARTINS-HATANO, F. ${ }^{2}$ \\ ${ }^{1}$ Departamento de Ecologia, Instituto de Biologia Roberto Alcântara Gomes, Universidade do Estado do Rio de Janeiro, \\ Rua São Francisco Xavier, 524, CEP 20559-900, Rio de Janeiro, RJ, Brazil \\ ${ }^{2}$ Pós-Graduação em Biologia, Área de Concentração em Ecologia, UERJ \\ Correspondence to: Helena Godoy Bergallo, Departamento de Ecologia, Instituto de Biologia Roberto Alcântara Gomes, \\ Universidade do Estado do Rio de Janeiro, Rua São Francisco Xavier, 524, CEP 20559-900, Rio de Janeiro, RJ, Brazil, \\ e-mail: bergallo@uerj.br \\ Received January 12, 2004 - Accepted April 13, 2004 - Distributed November 30, 2005
}

(With 3 figures)

\begin{abstract}
The Restinga de Jurubatiba has at least 10 plant formations, including open Clusia shrubland. This formation is composed of dense shrubs of many shapes and sizes, where Clusia hilariana is one of the most important plant species. Shrublands with Clusia (CC) are poorer in plant species and less dense than shrublands without Clusia (SC). Oryzomys subflavus (Rodentia) is the most abundant small mammal species in the open Clusia shrubland. We tested the hypothesis that the abundance of rodents would increase with the size of the patch and would be higher in SC shrublands. Rodents were captured, marked and released in three 780-m-long transects. At each capture site, we evaluated the shape of the shrubland patch, calculated the area and noted the category of the shrubland. Using ANCOVA, we ascertained whether the abundance of Oryzomys subflavus increased with the sampled area and used CC and SC shrublands differently. We also verified if the size of patches used by rodents varies in the same frequency as the size of available shrublands. Rodent abundance was found to increase significantly with the area. There were no differences in the size of the patches used by rodents and the frequency of the size of available patches. This finding indicates that $O$. subflavus, in the study area, is a generalist species that uses its habitat according to availability.
\end{abstract}

Keywords: Clusia hilariana, abundance, structure of shrublands, Restinga, Atlantic Forest.

\section{RESUMO}

\section{Uso do hábitat por Oryzomys subflavus (Rodentia) numa formação aberta de moitas no Parque Nacional da Restinga de Jurubatiba, RJ, Brasil}

A Restinga de Jurubatiba possui pelo menos 10 formações vegetais, entre elas a Arbustiva Aberta de Clusia. Esta formação é constituída por moitas densas de várias formas e tamanhos, sendo a espécie Clusia hilariana uma das mais importantes. Moitas com Clusia (CC) têm menor riqueza vegetal e são menos densas que moitas sem Clusia (SC). Oryzomys subflavus (Rodentia) é a espécie mais abundante de pequeno mamífero na Arbustiva Aberta de Clusia. Nós testamos a hipótese que a abundância do roedor aumentaria com o tamanho da área da moita e seria maior em moitas SC. Os roedores foram capturados, marcados e soltos em três transectos de 780 metros de extensão. Em cada ponto de armadilhamento, nós avaliamos a forma da moita, calculamos sua área e anotamos se era uma moita CC ou SC. Nós testamos por ANCOVA, se a abundância de $O$. subflavus aumentava com a área amostrada e se diferenciava em moitas CC ou SC. Nós também testamos se o tamanho das moitas usadas pelos roedores variavam na mesma freqüência que o tamanho de moitas disponíveis. A abundância do roedor aumentou com o aumento da área, mas as retas de regressão das moitas CC e SC não diferiram nem na inclinação e nem na elevação. O padrão na 
abundância de $O$. subflavus em diferentes classes de tamanho de moitas não diferiu do número disponível de moitas observadas por classes. Esses resultados indicam que $O$. subflavus é uma espécie generalista na área estudada, usando o hábitat de acordo com o que está disponível.

Palavras-chave: Clusia hilariana, abundância, estrutura da moita, Restinga, Mata Atlântica.

\section{INTRODUCTION}

"Restingas" are sand dune habitats characteristic of the Atlantic forest (lato sensu, see Oliveira-Filho \& Fontes, 2000) that occur in sandy lowlands along Brazil's coast. Restingas, which are composed of sandy substrates originating from marine deposits of the Quaternary period, frequently include freshwater or brackish lagoons (Araújo, 2000; Suguio \& Tessler, 1984; Turcq et al., 1986). These relatively open habitats include herbaceous formations along the seashore, shrub formations, forest formations in depressions and on sand dunes, and vegetation along the shores of lagoons (Araújo, 1992).

The restinga in Jurubatiba is the longest continuous area of restinga in the state of Rio de Janeiro (14,860 ha). In 1988, this restinga was declared an environmental conservation area and turned into a national park, called the "Parque Nacional da Restinga de Jurubatiba" (Restinga de Jurubatiba National Park; MMA, 1999). Araújo et al. (1998) identified 10 plant formations, whose occurrence is associated with topographic variations, distance from the ocean and variations in water table depth. The present study was conducted in one of these formations, called "Arbustiva Aberta de Clusia" (Open Clusia Shrubland), which consists of dense shrubs of many shapes and sizes, where Clusia hilariana Schltdl. (Clusiaceae) is one of the most important plant species. Pimentel (2002) stated that shrublands with Clusia are poorer in plant variety and less dense than shrublands without Clusia. Shrublands dominated by $C$. hilariana are rounded in shape and have an open and shaded interior (Pimentel, 2002), which lowers the range of temperature (Zaluar \& Scarano, 2000). In shrublands not dominated by $C$. hilariana no single dominant species is distinguishable and the vegetation is densely tangled (Pimentel, 2002).

Owing to the complexity of this taxon, the genus Oryzomys (Rodentia: Sigmodontinae) is divided into several groups of species (Bonvicino \& Moreira, 2001). The genus Oryzomys comprises at least five groups (Musser et al., 1998), of which the subflavus group is the least known (Bonvicino, 2003). Five variants (different karyotypes) of Oryzomys subflavus are known and they occur mainly in areas of open Cerrado vegetation (savanna-like habitat), Caatinga (semiarid habitat) and patches of savanna in the Amazonian Forest (Bonvicino, 2003; Bonvicino \& Moreira, 2001).

In Restinga de Jurubatiba National Park, the Oryzomys of the subflavus group has a karyomorphotype $(2 \mathrm{~N}=54, \mathrm{FN}=62)$ similar to that of the Oryzomys subflavus stricto sensu $(2 \mathrm{~N}=54-56, \mathrm{FN}=62-63)$ found in Minas Gerais, São Paulo and Bahia States (Bonvicino, 2003; Bonvicino \& Moreira, 2001; Langguth \& Bonvicino, 2002). Oryzomys subflavus is the most abundant species of the small mammal community in Restinga de Jurubatiba, inhabiting many formations, but in higher density in open Clusia shrublands (Bergallo et al., 2004).

The main goal of this study was to determine the habitat use of $O$. subflavus in Restinga de Jurubatiba. We began by verifying the possibility of a correlation between the maximum height of the vegetation and the size of the shrublands with (CC) and without Clusia (SC). We then tested the hypothesis that the abundance of rodents increases along with the size of the shrubland area and is greater in SC shrublands, which have a richer variety of plants and a denser layer of undergrowth (Pimentel, 2002). Those shrublands would presumably provide a greater abundance of food and better shelter for rodents compared to those of the same size with Clusia. Finally, we checked if $O$. subflavus uses the shrublands in the same frequency in which they are available.

\section{MATERIALS AND METHODS}

\section{Study area}

The study was conducted in Restinga de Jurubatiba National Park $\left(22^{\circ}\right.$ and $22^{\circ} 23^{\prime} \mathrm{S}$, $41^{\circ} 45^{\prime} \mathrm{W}$ ), located on the northern coast of the 
state of Rio de Janeiro and encompassing the municipalities of Macaé, Carapebus and Quissamã. The region is dominated by a freshwater lagoon (Lagoa Feia) and by a Quaternary sand plain (Araújo et al., 1998). The study area lies between the Cabiúnas and Comprida lagoons.

The rainfall is seasonal in the region, with an average minimum of $41 \mathrm{~mm}$ during the coolest months and an average maximum of $189 \mathrm{~mm}$ during the warmest months, and a groundwater deficit in July and September (Henriques et al., 1986).

The vegetation - open Clusia shrubland - where the study was conducted consists of dense patches of bushes of varying sizes intercalated with sparsely covered sandy stretches. The shrubby patches vary in size from less than $1 \mathrm{~m}^{2}$ to more than $1,000 \mathrm{~m}^{2}$, with small patches reaching a maximum height of $1.8 \mathrm{~m}$ and large ones reaching up to $5 \mathrm{~m}$ (Araújo et al., 1998; Pimentel, 2002). The most important species are Clusia hilariana, Protium icicariba, Erythoroxylum subsessile, Eugenia rotundifolia, Allagoptera arenaria, Aechmea nudicaulis, Neoregelia cruenta, Piloscereus arrabidae, Vernonia crotonoides, Baccharis arctostaphylloides and Croton macrocalyx.

\section{Field work}

Rodents were captured in three 780-m-long transects parallel to the coast, located in open Clusia shrubland. Each transect contained 40 trapping sites $20 \mathrm{~m}$ apart. Samples were collected at 3-month intervals from February 2001 to November 2002 during six consecutive nights. In each transect we set 20 Sherman or Tomahawk traps (in a 3:1 ratio) $40 \mathrm{~m}$ apart from each other. On the third day of sampling, the traps were moved $20 \mathrm{~m}$ to cover all the 40 trap sites.

The captured animals were identified, individually marked, brushed, weighed, measured, sexed and released at the same capture site. We made only one observation of each individual to avoid pseudoreplication (Hurlbert, 1984).

In each trap site, we evaluated roughly the shape of the shrub patch (triangular, square or circular) and measured its base, height or diameter to estimate the area. We also recorded the category of the patch, with or without Clusia, based on the presence or absence of $C$. hilariana. Some patches containing Clusia were classified as without Clusia because they were located at the edge of a patch or were smaller (less than or up to $1.5 \mathrm{~m}$ ) and thus did not characterize a patch dominated by $C$. hilariana with rounded shape and open, shaded interior (Pimentel, 2002). We also measured the height of the highest plant in each patch.

\section{Data analysis}

To evaluate the differences in vegetation height in the two categories of patches, we made a covariance analysis, using area as the covariate. In this analysis, we found that the formations without Clusia varied in area from 0.45 to $276.5 \mathrm{~m}^{2}$, except for one, which was $2,281 \mathrm{~m}^{2}$. We considered this one large patch an outlier and carried out the analysis using only patches of up to $300 \mathrm{~m}^{2}$ (Fig. 1). Using ANCOVA, we ascertained if the populational density of $O$. subflavus increased along with the sampled area and if the animal used patches with and without Clusia differently. Also, using the Mann-Whitney test, we verified whether the size of the patches used by rodents varied in the same frequency as the size of available patches. Our analyses and graphics were made with Systat 7.0 (Wilkinson, 1997).

\section{RESULTS}

The size of the CC patches varied from 2.84 to $1348.1 \mathrm{~m}^{2}\left(186.4+262.7 \mathrm{~m}^{2}, N=80\right)$, while the SC patches ranged from 0.45 to $2281.0 \mathrm{~m}^{2}$ $\left(113.6+359.7 \mathrm{~m}^{2}, N=40\right)$. In both CC and SC patches, the height of the plants increased as the patch size increased. Nevertheless, the height of plants in CC shrublands was significantly greater than in the SC shrublands, reaching up to $5 \mathrm{~m}$ (Fig. 1). Our covariance analysis showed no differences in the slope of the lines from $\mathrm{CC}$ and SC shrublands $(F=0.198, P=0.657)$, but the shrublands differed with respect to the intercept $(F=65.261, P<0.001)$ (Fig. 1).

The abundance of $O$. subflavus in the patches varied from 0 to 4 individuals $(X+S D$, $1.04+1.09$ ind./patch). Rodent population density increased significantly with the area $\left(r^{2}=0.366\right.$, $P=0.001, N=96)$, but neither the slope $(P=0.823)$ nor the intercept $(P=0.568)$ of the straight line differed between CC and SC shrublands (Fig. 2).

The Mann-Whitney test revealed no differences in the frequency of shrubland availability and $O$. subflavus density in shrubland $(U=52.5$, 
$P=0.848$ ), so the shrublands were used in the same frequency in which they appeared (Fig. 3).

\section{DISCUSSION}

The structure of the shrublands in question, insofar as plant height and size are concerned, was very similar to that studied by Pimentel (2002). CC shrublands were usually larger and taller than the SC shrublands, with $C$. hilariana being the tallest plants.
For $O$. subflavus, the differences in plant height and species richness between CC and SC shrublands did not affect the animal's choice. We found that larger shrublands housed a greater rodent density, but there was no discrimination in terms of shrub category.

O'Connell (1982) considered Oryzomys subflavus a frugivorous/omnivorous species while Fonseca et al. (1996) believed it to be frugivorous/ granivorous. Stallings (1989) found the stomach of

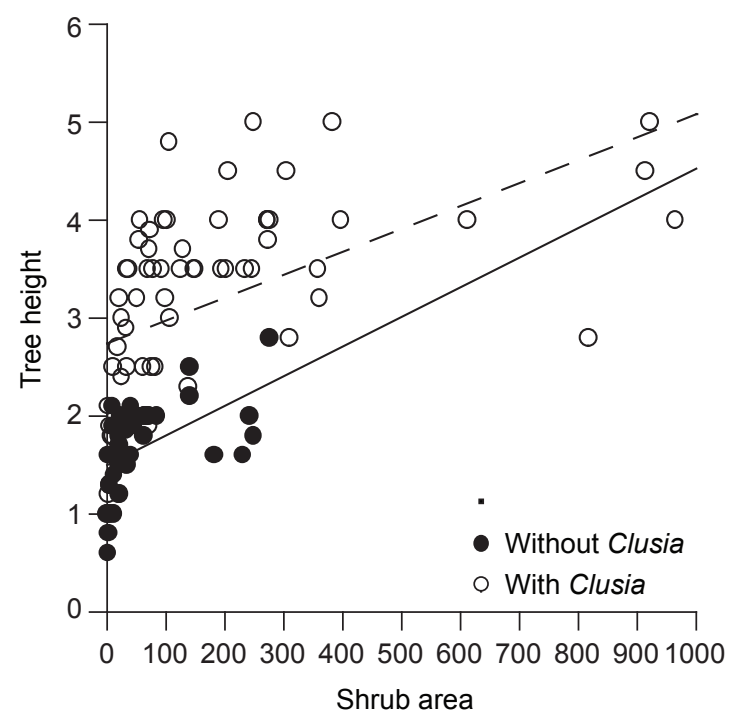

Fig. 1 - Correlation between tree height $(\mathrm{m})$ and shrubland area $\left(\mathrm{m}^{2}\right)$ with and without Clusia at Restinga de Jurubatiba National Park.

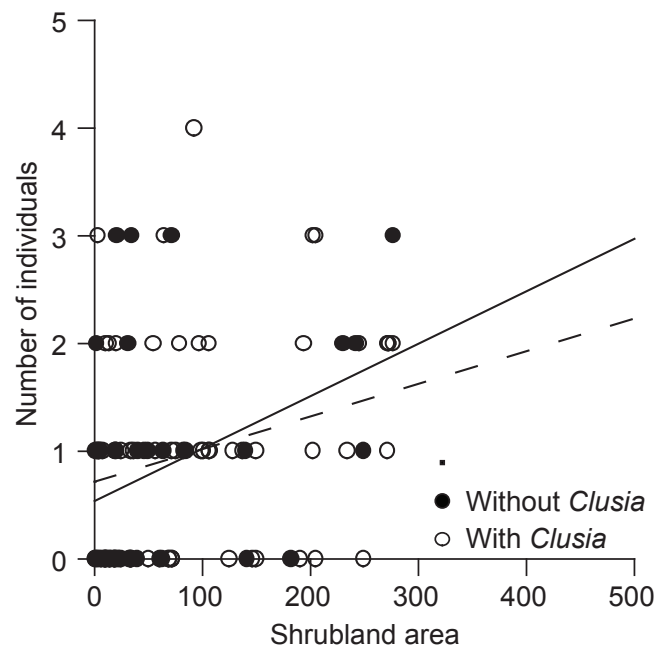

Fig. 2 - Correlation between the number of individuals of $O$. subflavus and shrubland area $\left(\mathrm{m}^{2}\right)$ with and without $C l u s i a$ at Restinga de Jurubatiba National Park. 


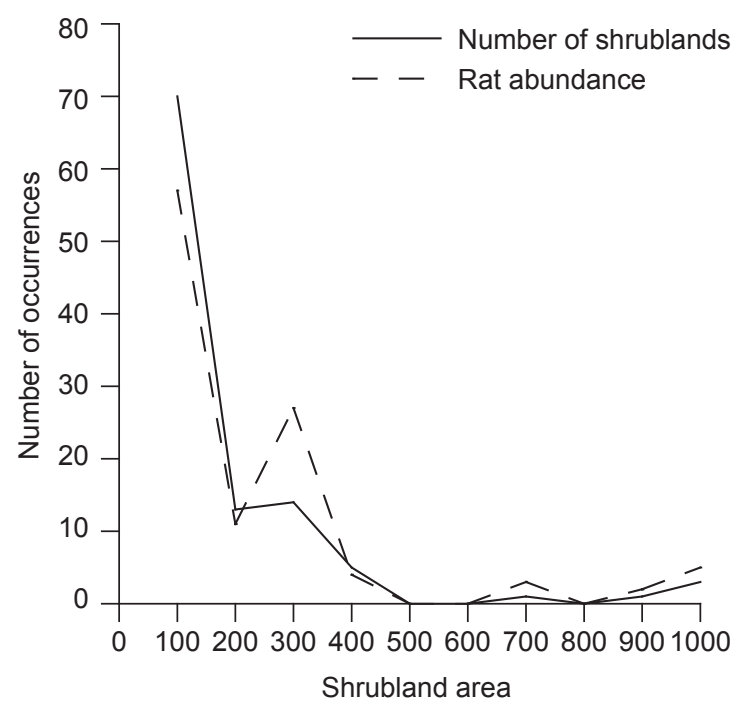

Fig. 3 - Number of occurrences of shrubland and O. subflavus in different classes of shrubland area $\left(\mathrm{m}^{2}\right)$ at Restinga de Jurubatiba National Park.

one specimen contained $95 \%$ grass and $5 \%$ fruit. Talamoni et al. (1999) reported the same tendency for herbivority. In the Serra do Cipó mountains, state of Minas Gerais, specimens of $O$. subflavus fed on plant material and invertebrates (E. M.V.C. Camara, pers. com.), as did the specimens examined in the present study at Restinga de Jurubatiba (pers. obs.), confirming O'Connell's (1982) observations. Since the SC shrubland is denser, richer in plant species and probably richer in invertebrates, we had expected that $O$. subflavus would prefer this type of shrubland. However, the animal's indiscriminate use of shrubland categories did not corroborate our hypothesis. Nevertheless, nests of this species have often been found in tangled bromeliads, which are common in CC shrublands (F. Martins-Hatano, pers. obs.).

The fact that the abundance of shrub patches used by $O$. subflavus displayed the same pattern of availability as the shrublands in the environment seems to indicate that the species is a habitat generalist, using habitat according to availability. Nevertheless, on a larger scale, this species of the subflavus group appears to favor open habitats (e.g., Bergallo et al., 2004; Bonvicino, 2003) in the Restinga de Jurubatiba. Alho (1981) also observed that the abundance of Oryzomys subflavus (= subflavus group) increased with decreasing soil cover and fewer trees in the Cerrado habitats in Central Brazil.

Of the small mammal species found in the Restinga de Jurubatiba, $O$. subflavus was the only one recorded in open Clusia shrubland. The other eight species of rodents and marsupials (excluding exotic species) occurred in more closed formations or in swamps (Bergallo et al., 2004), probably because they are more dependent on humidity (Cerqueira, 2000). According to Cerqueira (2000), the mammal fauna of restinga comprises a subset of the Atlantic forest fauna. Oryzomys subflavus appears to be an exception, since it is a species inhabiting open areas such as Cerrado.

The vegetation also follows this pattern, with a floristic composition similar to that of the Atlantic forest. Thus, zoochory is observed in $80 \%$ of the plants found in open Clusia shrubland, which is the same proportion found in the Atlantic forest (Pimentel, 2000). Nevertheless, clonal growth is favoured in habitats with low productivity such as restinga, (Pimentel, 2000). Studies on O. subflavus diet should be carried out at the Restinga de Jurubatiba, for they can provide information on the dispersion role of the species in such habitats, affecting the distribution and abundance of plant species. 
Acknowledgments - This study is part of the Long-Term Ecological Research Program - PELD, funded by CNPq/MCT/ site5 - Restinga de Jurubatiba and the Brazilian Southeast Ecosystem Ecology, Conservation and Management Program of the Department of Ecology, Institute of Biology, Rio de Janeiro State University. We thank T.P. Moulton, C.E.V. Grelle and D. Vrcibradic for their helpful comments on the manuscript. We are indebted to Aline Gaglia Alves, Tatiana Teixeira Leite Ribeiro, Renato Mangolin and Marco Aurélio Ribeiro de Mello, who assisted us with the field work. Lena Geise and Luciana G. Pereira kindly karyotyped and identified the rodent species.We gratefully acknowledge CNPq for the grant to HGB (Process No. 462003/00-0) and fellowships to HGB (productivity fellowship), JLL and DSR (undergraduate fellowships) and FMH (graduate fellowship). We thank CAPES for the graduate fellowship to FHH. Lastly, we are indebted to IBAMA for granting us a collection permit.

\section{REFERENCES}

ALHO, C. J. R., 1981, Small mammal populations of Brazilian cerrado: the dependence of abundance and diversity on habitat complexity. Rev. Brasil. Biol., 41: 223-230.

ARAÚJO, D. S. D, 1992, Vegetation types of sandy coastal plains of tropical Brazil: a first approximation. In: Seeliger, U. (ed.) Coastal Plant Communities of Latin America. pp. 337-347. Academic Press, Inc, San Diego.

ARAÚJO, D. S. D, 2000, Análise florística e fitogeográfica das Restingas do Estado do Rio de Janeiro. Tese de Doutorado. Universidade Federal do Rio de Janeiro. Rio de Janeiro. $179 \mathrm{p}$.

ARAÚJO, D. S. D., SCARANO, F. R., SÁ C. F.C., KURTZ, B. C., ZALUAR, H. L. T., MONTEZUMA, R. C. M. \& OLIVEIRA, R. C, 1998, As comunidades vegetais do Parque Nacional da Restinga de Jurubatiba, Macaé, RJ. In: Esteves, F.A. (ed.). p. 39-62. Ecologia das lagoas costeiras do Parque Nacional da Restinga de Jurubatiba e do Município de Macaé (RJ). NUPEM / UFRJ.

BERGALLO, H. G., MARTINS-HATANO, F. RAÍCES, D. S., RIBEIRO, T. T. L., ALVES, A. G., LUZ, J. L., MANGOLIN, R. \& MELLO, M. A. R., 2004, Os Mamíferos da Restinga de Jurubatiba. In: ROCHA, C. F. D.; ESTEVES, F. A. \& SCARANO, F. R. (eds.). p. 215-230. Pesquisas de longa duração na Restinga de Jurubatiba. Ecologia, história natural e conservação. Editora Rima, São Carlos, SP.

BONVICINO, C. R., 2003, A new species of Oryzomys (Rodentia, Sigmodontinae) of the subflavus group from the Cerrado of Central Brazil. Mamm. Biol., 68: 78-90.

BONVICINO, C. R. \& MOREIRA, M. A. M., 2001, Molecular phylogeny of the genus Oryzomys (Rodentia: Sigmodontinae) based on cytochrome $b$ DNA sequences. Mol. Phylogen. Evol. 18: 282-292.

CERQUEIRA, R., 2000, Ecologia funcional de mamíferos numa restinga do Estado do Rio de Janeiro. In: ESTEVES, F. A. \& LACERDA, L. D. (eds.). Ecologia de restingas e lagoas costeiras. p. 189-212. Nupem/UFRJ, Macaé, Brasil.

FONSECA, G. A. B., HERMAN, G., LEITE, Y. L., MITTERMEIER, R., RYLANDS, A. B. \& PATTON, J. L.,
1996, Lista Anotada dos Mamíferos do Brasil. Occ. Pap. Conserv. Biol., Washington, DC 4: 1-38.

HENRIQUES, R. P. B., ARAÚJO, D. S. D. \& HAY, J. D, 1986, Descrição e classificação dos tipos de restinga de Carapebús, Rio de Janeiro. Rev. Brasil.Bot., 9: 173-189.

HURLBERT, S. H., 1984, Pseudoreplication and the design of ecological field experiments. Ecol. Monogr., 54: 187-211.

LANGGUTH, A. \& BONVICINO, C. R., 2002, The Oryzomys subflavus species group, with description of two new species (Rodentia, Muridae, Sigmodontinae). Arq. Mus. Nac., Rio de Janeiro, 60: 285-294.

MMA, 1999, Parques Nacionais: Brasil. Empresa das Artes, São Paulo.

MUSSER, G. C., CARLETON, M. D., BROTHERS, E. M. \& GARDNER, A. L., 1998, Systematic studies of oryzomyine rodents (Muridae, Sigmodontinae): diagnoses and distributions of species formely assigned to Oryzmoys "capito". Bull. Amer. Mus. Nat. Hist., New York, 236: $1-376$.

O’CONNELL, M. A., 1982, Population biology of North and South American grassland rodents: a comparative review. In: MARES, M. A. \& GENOWAYS, H. H. (eds.). Mammalian biology in South America. pp. 167-186. Pymatuning Laboratory of Ecology, University of Pittsburgh.

OLIVEIRA-FILHO, A. T. \& FONTES, M. A. L., 2000, Patterns of floristic differentiation among Atlantic forests in southeastern Brazil, and the influence of climate. Biotropica 32(4b): 793-810.

PIMENTEL, M., 2002, Variação espacial na estrutura de comunidades vegetais da formação aberta de Clusia no Parque Nacional da Restinga de Jurubatiba, RJ. Tese de Doutorado, Pós-Graduação em Ecologia, UFRJ, Rio de Janeiro, RJ, 81 pp.

STALLINGS, J. R., 1989, Small mammal inventories in an Eastern Brazilian park. Bull. Florida State Mus., Biol. Sci., 34: $153-200$

SUGUIO, K. \& M. G. TESSLER, 1984, Planícies de cordões litorâneos Quaternários do Brasil: Origem e nomenclatura. In: LACERDA, L. D., ARAÚJO, D. S. D., CERQUEIRA, R. \& TURCQ, B. (eds.), Restingas: origem, estrutura e processos. pp 32-56. Centro Editorial da Universidade Federal Fluminense, CEUFF, Niterói, Rio de Janeiro.

TALAMONI, S. A., COUTO, D., LOPES, M. O. G. \& D. A. CORDEIRO J. R., 1999, Dieta de algumas espécies de pequenos mamíferos do sudeste brasileiro. Bios, 7: 51-56.

TURCQ, B.; R. COE NETO \& J. M. FROIDEFOND, 1986, Variability of beach ridges on the coast of Maricá (Rio de Janeiro, Brasil). In: J. RABASA (ed.), Quaternary of South America and Antartic Peninsula. Vol. 4. A, Balkema, Rotterdam.

WILKINSON, L., 1997, SYSTAT® 7.0: Statistics. SPSS Inc. Chicago, Illinois, $751 \mathrm{pp}$.

ZALUAR, H. L. T. \& F. R. SCARANO, 2000, Facilitação em restingas de ilhas. Um século de buscas por espécies focais. In: ESTEVES, F. A. \& LACERDA, L. D. (eds.) Ecologia das restingas e lagoas costeiras. Pp 3-23. UFRJ, Rio de Janeiro. 